\title{
The transcription factor HIF-1 $\alpha$ plays a critical role in the growth factor-dependent regulation of both aerobic and anaerobic glycolysis
}

\author{
Julian J. Lum, ${ }^{1,2}$ Thi Bui, ${ }^{1,2}$ Michaela Gruber, ${ }^{1}$ John D. Gordan, ${ }^{1}$ Ralph J. DeBerardinis, ${ }^{1,2,3}$ \\ Kelly L. Covello, ${ }^{1}$ M. Celeste Simon, ${ }^{1,4}$ and Craig B. Thompson ${ }^{1,2,5}$ \\ ${ }^{1}$ Abramson Family Cancer Research Institute, University of Pennsylvania School of Medicine, Philadelphia, Pennsylvania \\ 19104, USA; ${ }^{2}$ Department of Cancer Biology, University of Pennsylvania School of Medicine, Philadelphia, Pennsylvania \\ 19104, USA; ${ }^{3}$ Division of Child Development, Rehabilitation Medicine and Metabolic Disease, Department of Pediatrics, \\ Children's Hospital of Philadelphia, Philadelphia, Pennsylvania 19104, USA; ${ }^{4}$ Howard Hughes Medical Institute, \\ Philadelphia, Pennsylvania 19104, USA
}

\begin{abstract}
Mammalian cells are believed to have a cell-intrinsic ability to increase glucose metabolism in response to hypoxia. Here we show that the ability of hematopoietic cells to up-regulate anaerobic glycolysis in response to hypoxia is dependent on receptor-mediated signal transduction. In the absence of growth factor signaling, hematopoietic cells fail to express hypoxia-inducible transcription factor $($ Hif-1 $\alpha)$ mRNA. Growth factor-deprived hematopoietic cells do not engage in glucose-dependent anabolic synthesis and neither express Hif-1 $\alpha$ mRNA nor require HIF-1 $\alpha$ protein to regulate cell survival in response to hypoxia. However, HIF-1 $\alpha$ is adaptive for the survival of growth factor-stimulated cells, as suppression of HIF-1 $\alpha$ results in death when growing cells are exposed to hypoxia. Growth factor-dependent HIF-1 $\alpha$ expression reprograms the intracellular fate of glucose, resulting in decreased glucose-dependent anabolic synthesis and increased lactate production, an effect that is enhanced when HIF-1 $\alpha$ protein is stabilized by hypoxia. Together, these data suggest that HIF-1 $\alpha$ contributes to the regulation of growth factor-stimulated glucose metabolism even in the absence of hypoxia.
\end{abstract}

[Keywords: HIF-1 $\alpha$; hypoxia; growth factor signaling; glucose metabolism; cell survival]

Supplemental material is available at http://www.genesdev.org.

Received January 8, 2007; revised version accepted March 8, 2007.

Unlike unicellular eukaryotes, mammalian cells have been shown to lack the cell-autonomous ability to capture and utilize extracellular nutrients. Instead, mammalian cells depend on growth factor signal transduction to direct the uptake of nutrients and their subsequent intracellular metabolism. Previous work has demonstrated that growth factor signal transduction is required to maintain the surface expression of nutrient transporters and the expression/function of proximal glycolytic enzymes (Rathmell et al. 2000; Bentley et al. 2003). Growth factor regulation of nutrient utilization has been proposed to have evolved to prevent cell-autonomous utilization of the shared metabolic resources of an organism. Extrinsic control of cellular nutrient uptake would limit the success of viral parasitism and act as a barrier to cellular transformation.

One potential exception to the dependence of mammalian cells on receptor signaling to regulate nutrient

${ }^{5}$ Corresponding author.

E-MAIL craig@mail.med.upenn.edu; FAX (215) 746-5511.

Article published online ahead of print. Article and publication date are online at http://www.genesdev.org/cgi/doi/10.1101/gad.1529107. uptake is the ability of cells to alter their cellular metabolism in response to oxygen availability. When mammalian cells are exposed to hypoxia in tissue culture, the cells have been found to increase their rate of glycolysis. This up-regulation of glycolysis has been proposed to be a cell-intrinsic property and results from the posttranslational stabilization of the hypoxia-inducible transcription factor HIF-1 (Semenza et al. 1996; Seagroves et al. 2001; Semenza 2003; Pouyssegur et al. 2006). Under normoxic conditions, HIF-1 is believed to be constitutively transcribed and translated. In cells growing in growth factor-containing medium, HIF-1 expression is controlled post-translationally by a class of prolyl hydroxylase enzymes that modify critical proline residues on the HIF-1 $\alpha$ subunit of HIF-1 (Jaakkola et al. 2001; Yu et al. 2001). This hydroxlyation results in the recognition and ubiquitination of HIF- $1 \alpha$ by the von Hippel-Lindau tumor suppressor (pVHL) targeting it for proteasomal degradation (Maxwell et al. 1999). Hypoxia inhibits the action of prolyl hydroxylases and prevents degradation of HIF- $1 \alpha$, thereby activating genes involved in glycolysis, angiogenesis, and cell survival (Semenza 2003; Pouyssegur 
et al. 2006). Hypoxia-independent mechanisms to regulate HIF- $1 \alpha$ have also been proposed. In certain tumors, high levels of HIF-1 $\alpha$ are observed in well-oxygenated environments and deficiencies in the mitochondrial enzymes, succinate dehydrogenase and fumarase, have been associated with stabilization of HIF-1 $\alpha$ under normoxic conditions (Isaacs et al. 2005; Selak et al. 2005).

Growth factor signal transduction has also been suggested to enhance HIF-1 $\alpha$ expression (Jiang et al. 1997; Richard et al. 2000; Semenza 2003). In certain cell types, activation of the phosphatidylinositol-3-kinase (PI3K) and mitogen-activated protein kinase (MAPK) pathways is associated with an increase in HIF- $1 \alpha$ protein translation (Richard et al. 1999; Zhong et al. 2000; Jiang et al. 2001; Laughner et al. 2001; Fukuda et al. 2002; Bardos et al. 2004; Kasuno et al. 2004). Genetic mutations that result in hyperactivation of oncogenic signal transduction pathways such as Ras, Src, and HER2/Neu also enhance HIF-1 $\alpha$ expression (Jiang et al. 1997; Laughner et al. 2001; Karni et al. 2002; Semenza 2003; Wang et al. 2004; Blum et al. 2005; Li et al. 2005). Other environmental stresses including reactive oxygen species (ROS), nitric oxide, and heat shock have also been reported to promote HIF- $1 \alpha$ expression under normoxic conditions (Isaacs et al. 2002; Kasuno et al. 2004; Brunelle et al. 2005; Guzy et al. 2005; Lu et al. 2005; Mansfield et al. 2005; M. Wang et al. 2005).

Recently, it has been suggested that growth factor stimulation is the primary regulator of glucose uptake in mammalian cells. Growth factor-dependent signal transduction can direct glucose uptake that is in excess of cellular needs (Bauer et al. 2004). When glucose uptake exceeds cellular demand epithelial and hematopoietic cells secrete the excess carbon as lactate. This growth factor-stimulated form of metabolism has been termed aerobic glycolysis. A major advantage of this form of metabolism is that a high intracellular glucose concentration allows the cell to engage in a truncated tricarboxylic acid cycle (TCA) that supports glucose-to-lipid synthesis (Ruderman et al. 1999; Hatzivassiliou et al. 2005) and to suppress mitochondrial amino acid catabolism so that available amino acids are redirected into protein synthesis. Another potential advantage of the high rate of aerobic glycolysis is that cells are less dependent on oxidative metabolism to supply their bioenergetic needs (Brand 1985). While oxidative metabolism is more efficient, glycolytic ATP production can respond to changing bioenergetic demand more rapidly (Bui and Thompson 2006). However, how cells regulate the utilization of pyruvate between mitochondrial-dependent lipid synthesis and cytosolic lactate production has not been determined. Here we provide evidence that HIF- $1 \alpha$ is a critical and growth factor-dependent component of that regulation.

Neither the expression of HIF- $1 \alpha$ nor the ability to up-regulate glycolysis in response to hypoxia is a cellintrinsic property. Instead, a hematopoietic cell's ability to express HIF- $1 \alpha$ is dependent on receptor-mediated signal transduction. In turn, HIF- $1 \alpha$ is required for the survival and adaptation of growth factor-stimulated cells to hypoxia. When HIF-1 $\alpha$ was suppressed by short hairpin RNA (shRNA), growth factor-stimulated cells engaged in an increased conversion of pyruvate into lipids and a decrease in the level of lactate secretion despite being cultured in normoxia. This increase in de novo lipid synthesis correlated with a higher rate of growth and proliferation. Together, this provides a demonstration that HIF- $1 \alpha$ is a key component of growth factor-induced aerobic glycolysis.

\section{Results}

Hypoxia-induced changes in glucose metabolism are growth factor-dependent

Recent studies have suggested that the primary determinant of the glycolytic rate of mammalian cells is growth factor-dependent signal transduction (Vander Heiden et al. 2001; Bauer et al. 2004). To investigate whether growth factor signaling is also required for hypoxiainduced increases in glycolysis, IL-3-dependent cells were cultured in the presence or absence of IL-3 and then exposed to $1.5 \%$ oxygen. Hypoxia induced a threefold increase in anaerobic glycolysis when cells were cultured in the presence of IL-3. In contrast, IL-3-deprived cells failed to up-regulate glycolysis when exposed to hypoxia for $24 \mathrm{~h}$ (Fig. 1A). This was not due to an inability to up-regulate glycolysis, as these same cells responded to growth factor readdition with a sevenfold to 10 -fold increase in glycolysis (data not shown).

In growth factor-stimulated cells, a major intracellular fate of glycolytic pyruvate is mitochondrial-dependent conversion to acetyl-CoA to fuel the fatty acid and isoprenoid synthesis required for cell growth (Ruderman et al. 1999; Hatzivassiliou et al. 2005). Consistent with these prior observations, normoxic cells cultured in the presence of IL-3 converted glucose into lipids, and this
A

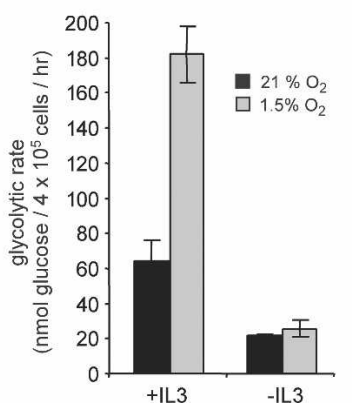

B

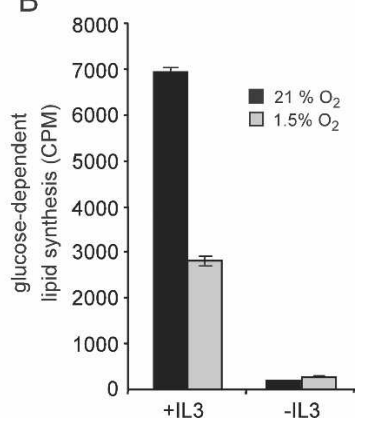

Figure 1. Induction of glycolysis by hypoxia is dependent on growth factor signals. (A) Cells were cultured in the presence or absence ( $3 \mathrm{wk}$ ) of IL-3. Following $24 \mathrm{~h}$ incubation at $21 \% \mathrm{O}_{2}$ or $1.5 \% \mathrm{O}_{2}$, cellular glucose utilization was measured by the conversion of $5-{ }^{3} \mathrm{H}$-glucose to ${ }^{3} \mathrm{H}_{2} \mathrm{O}$. Data represent mean of three independent experiments \pm SD. (B) Glucose-dependent lipid synthesis was measured by labeling cells with $\mathrm{D}-\left[\mathrm{U}_{-}{ }^{14} \mathrm{C}_{6}\right]$ glucose for $24 \mathrm{~h}$. Lipid extracts were obtained from $2 \times 10^{6}$ cells as described in the Materials and Methods. Data are a representative experiment performed in triplicate \pm SD. 
glucose-to-lipid synthesis ceased when the cells were deprived of IL-3 (Fig. 1B). Despite the fact that the glycolytic rate of IL-3-stimulated cells increased in response to hypoxia, IL-3-stimulated cells experienced a $60 \%$ decline in glucose-derived lipid synthesis, suggesting that the cells had undertaken a reprogramming of glucose metabolism.

\section{Growth factor signaling is required for hypoxia induction of HIF-1 $\alpha$}

Transcriptional profiling has implicated HIF- $1 \alpha$ in regulating the expression of an array of glucose metabolizing enzymes that are distinct from nonglycolytic targets mediated by HIF-2 $\alpha$ (Hu et al. 2003; V. Wang et al. 2005). This suggested that HIF-1 $\alpha$ might be involved in the growth factor-mediated reprogramming of anaerobic glycolysis and glucose-to-lipid synthesis that we observed during hypoxia. To examine the growth factor dependence of HIF-1 $\alpha$ expression and transcription, cells were cultured in the presence or absence of IL-3 and subjected to hypoxia for $4 \mathrm{~h}$. Stabilization of HIF- $1 \alpha$ and expression of its target pyruvate dehydrogenase kinase 1 (PDK-1) was detectable by Western blot analysis of lysates from cells cultured in medium containing IL-3 (Fig. 2A). However, within $4 \mathrm{~d}$ of IL-3 withdrawal neither HIF-1 $\alpha$ nor PDK-1 induction could be detected in cells that were exposed to hypoxia (Fig. 2A). This effect did not reflect a decrease in oxygen needs of growth factor-deprived cells, as treatment with $\mathrm{CoCl}_{2}$ also failed to stabilize HIF-1 $\alpha$ after IL-3 deprivation (Fig. 2B). Consistent with the fail- ure to stabilize HIF- $1 \alpha$, the induction of PDK-1 expression in response to $\mathrm{CoCl}_{2}$ treatment diminished in the absence of IL-3. Even persistent exposure to hypoxia (72 h) failed to stabilize HIF-1 $\alpha$ (data not shown). Cell death could not account for the lack of HIF-1 $\alpha$ expression, as no significant loss in viability was observed in cells cultured for $72 \mathrm{~h}$ at $1.5 \%$ oxygen. The STAT3 transcription factor downstream from the IL-3 receptor pathway was used as a loading control and Western blotting indicated that loss of HIF- $1 \alpha$ was not the result of a general suppression of genes involved in cell growth and survival.

Next, changes in Hif- $1 \alpha$ mRNA expression were examined using real-time quantitative PCR (qPCR). In the presence of IL-3, cells cultured under hypoxia exhibited a 2.5-fold increase in Hif- $1 \alpha$ mRNA levels. When cells were cultured in the absence of IL-3, Hif-1 $\alpha$ mRNA decreased over time and growth factordeprived cultures failed to increase Hif- $1 \alpha$ mRNA levels when exposed to $1.5 \%$ oxygen (Fig. 2C). This growth factor-dependent regulation of Hif- $1 \alpha$ mRNA was mirrored by similar changes in the mRNA levels of the HIF-1 $\alpha$ target, Glut1. In response to hypoxia, IL-3 stimulation resulted in a 2.5-fold increase in Glut1 levels. However, cells cultured in the absence of IL-3 displayed a progressive decline in Glut1 mRNA that failed to increase upon exposure to hypoxia (Fig. 2D).

As a test of HIF-1 $\alpha$ function, the ability of hypoxia to increase HIF- $1 \alpha$-dependent transcription was measured using a reporter construct containing a promoter with a

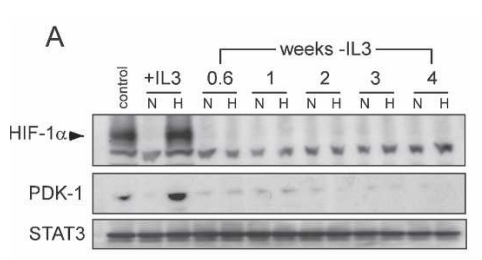

B
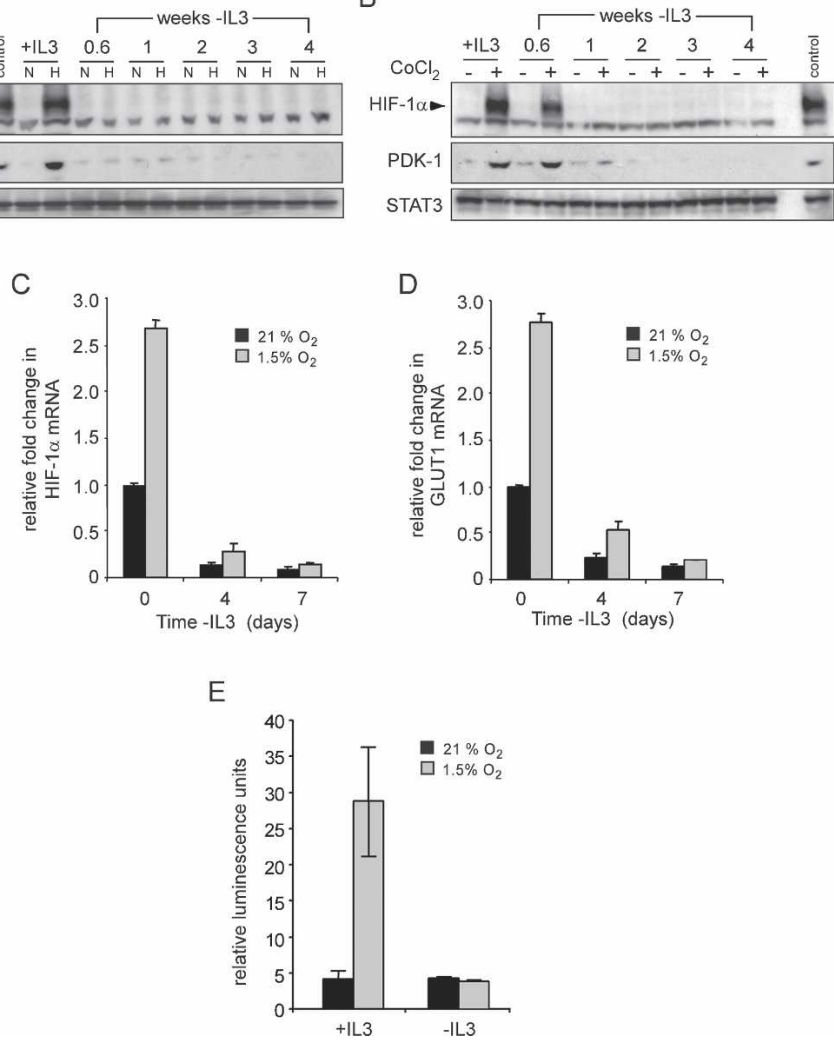

Figure 2. Growth factors regulate the expression and activity of HIF-1 $\alpha$. (A) Cells cultured in the presence (+IL3) or absence of IL-3 at the indicated time points were incubated in normoxic $(\mathrm{N})$ or hypoxic $(\mathrm{H})$ conditions for $4 \mathrm{~h}$ and HIF-1 $\alpha$ protein levels were analyzed by Western blot. Cells cultured in the presence of IL-3 and treated with $100 \mu \mathrm{M} \mathrm{CoCl}_{2}$ were used as a control. $(B)$ At similar time points following withdrawal from IL-3, cells were treated with PBS or $100 \mu \mathrm{M} \mathrm{CoCl}_{2}$ for $4 \mathrm{~h}$ and analyzed by Western blot for HIF-1 $\alpha$ and PDK-1 protein levels. Lysates from cells cultured in the presence of IL-3 exposed to hypoxia were used as a control. STAT3 was used as a loading control. Cells were cultured in the presence or absence of IL-3, and at the indicated time points, total RNA was isolated and analyzed for Hif-1 $\alpha$ $(C)$ or Glut1 $(D)$ mRNA levels by real-time qPCR. Data are a representative experiment for triplicate samples \pm SD. $(E)$ HIF-1 $\alpha$ promoter activity in response to hypoxia is lost during growth factor withdrawal. HIF$1 \alpha$-responsive promoter containing three tandem HRE from the murine $p g k 1$ was transfected into cells cultured in the presence or absence ( $3 \mathrm{wk}$ ) of IL-3. Ten hours after transfection, cells were incubated in normoxic $\left(21 \% \mathrm{O}_{2}\right)$ or hypoxic $\left(1.5 \% \mathrm{O}_{2}\right)$ conditions for an additional $24 \mathrm{~h}$. Promoter activity is expressed as a ratio of luciferase to Renilla activity (relative luminescence units). Data are a representative experiment \pm SD. for triplicate samples. 
HIF- $1 \alpha$-responsive element. Cells grown in the presence of IL-3 displayed a sixfold increase in HIF-dependent transcriptional activity when cultured under hypoxic conditions (Fig. 2E). However, growth factor-deprived cells exposed to hypoxia failed to induce HIF-dependent transcription.

\section{Glycolytic recovery after growth factor restimulation occurs prior to detectable HIF-1 $\alpha$ expression}

HIF- $1 \alpha$-dependent transcription induces the expression of a number of glycolytic genes, leading some investigators to hypothesize that HIF-1 $\alpha$ is a required cofactor in the expression of glycolytic targets (Seagroves et al. 2001; Semenza 2003; Pouyssegur et al. 2006). Therefore, growth factor-dependent regulation of HIF-1 $\alpha$ expression might be sufficient to explain how IL-3 signal transduction regulates glycolysis. When IL-3-deprived cells are restimulated with exogenous IL-3, the cells rapidly recovered the ability to take up and utilize glucose (Lum et al. 2005). Within $24 \mathrm{~h}$ of IL-3 readdition, the glycolytic rate recovered to a level that is indistinguishable from that of cells grown in the continuous presence of IL-3 (Fig. 3A). As an initial test of whether HIF-1 $\alpha$ contributes to this response, we measured the time course of hypoxia-inducible recovery of HIF- $1 \alpha$ upon IL-3 readdition. Hypoxia-inducible expression of HIF- $1 \alpha$ protein and its target PDK-1 did not fully recover until $3 \mathrm{~d}$ after IL-3 readdition despite glycolytic recovery in $24 \mathrm{~h}$ (Fig. 3B). The recovery of growth factor-induced glucose uptake and metabolism does not correlate temporally with the recovery of observable HIF- $1 \alpha$ protein expression, suggesting that growth factor stimulation of glycolysis may not be absolutely dependent on HIF- $1 \alpha$.

\section{Effects of HIF-1 $\alpha$ suppression on cell survival and proliferation}

To more completely assess the role of HIF-1 $\alpha$ in growth factor stimulation of glycolysis, we generated a panel of independently derived cell clones stably expressing an shRNA against HIF- $1 \alpha$. Two of these clones along with a clone stably expressing the shRNA vector were chosen for further study. In contrast to cells expressing a vector control, HIF-1 $\alpha$ knocked-down clones had reduced Hif- $1 \alpha$ mRNA abundance (Fig. 4A). The effect of shRNA targeting HIF- $1 \alpha$ was further demonstrated by assessing the hypoxia-inducible protein levels of HIF-1 $\alpha$ and its target PDK-1. As seen in Figure 4B, the shRNA clones C3 and $\mathrm{C} 18$ have reduced and undetectable levels of both HIF- $1 \alpha$ and PDK-1 protein, respectively, in comparison with the control clone. Next, the clones were tested to determine if cell survival under hypoxic conditions was affected by suppression of HIF-1 $1 \alpha$. After $5 \mathrm{~d}$ of exposure to $1.5 \%$ oxygen in the presence of IL-3, $>70 \%$ of control cells remained viable. In contrast, cells lacking HIF- $1 \alpha$ displayed a time-dependent decrease in viability (Fig. $4 C)$. However, both vector and HIF- $1 \alpha$ shRNA cells deprived of IL-3 and then exposed to $1.5 \%$ oxygen maintained a high level of viability (Fig. 4D). Together, these
A

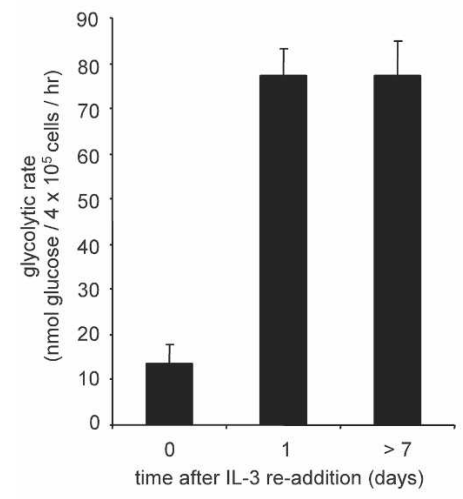

B

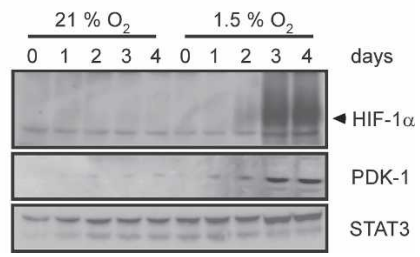

Figure 3. Control of glycolytic recovery following growth factor restimulation does not involve HIF-1 $\alpha$ expression. (A) Glycolytic rate of cells cultured in the absence of growth factor for $4 \mathrm{wk}$ was measured at the indicated time points following readdition of IL-3. Graph is a representative experiment plotted as the mean \pm SD of one triplicate experiment. $(B)$ At various time points following IL-3 readdition, cells were subjected to normoxic or hypoxic conditions for an additional $4 \mathrm{~h}$. Cell lysates were collected and Western blot analysis was used to measure HIF- $1 \alpha$ and PDK-1 protein levels. STAT3 was used as a loading control.

results demonstrate that IL-3 stimulation renders cells susceptible to hypoxia-inducible cell death in the absence of HIF- $1 \alpha$ and that HIF- $1 \alpha$ is dispensable for survival during hypoxia in cells withdrawn from IL-3.

While expression of HIF- $1 \alpha$ is required for growth factor-stimulated cells to adapt to hypoxic conditions, a contrasting result was observed when the HIF- $1 \alpha$ shRNA and control clones were passaged under conditions of normoxia. Normoxic growth curves revealed that shRNA suppression of HIF-1 $\alpha$ resulted in a significant increase in cell accumulation compared with vector control cells (Fig. 4E). The normoxic increase in cell accumulation observed in the growth factor-dependent HIF$1 \alpha$ knockdown cells was supported by an elevated rate of oxygen consumption. Consistent with the reduced levels of PDK-1 observed in the HIF-1 $\alpha$ knockdown cells, these cells also displayed an enhanced mitochondrial membrane potential in comparison with the control cells (Fig. $4 F, G)$. This proliferation advantage was not unique to IL-3-dependent hematopoietic cells. A similar proliferation advantage was also observed when HIF-1 $\alpha$ levels were suppressed by shRNA in two independent clones of a renal carcinoma cell line as demonstrated by an increase in the number of population doublings over a 12-d 
A

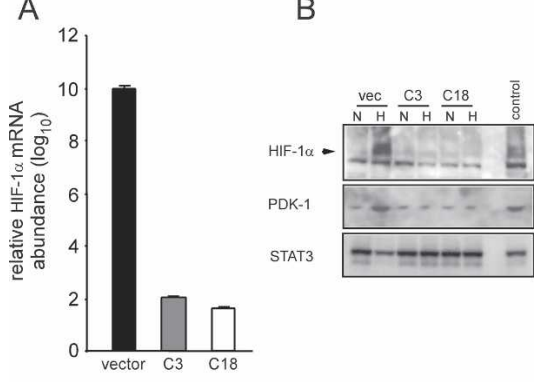

E

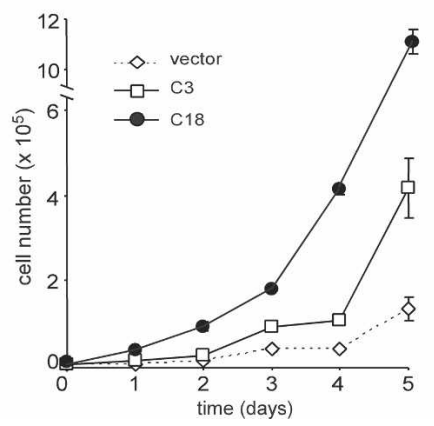

C

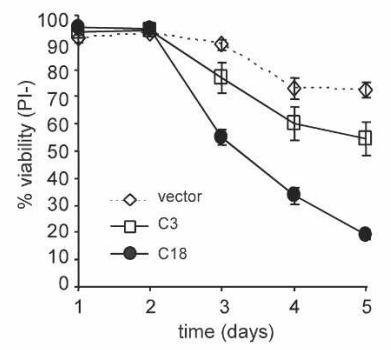

F

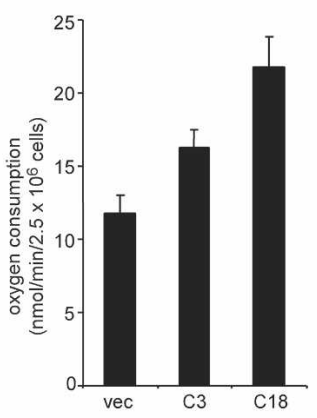

D

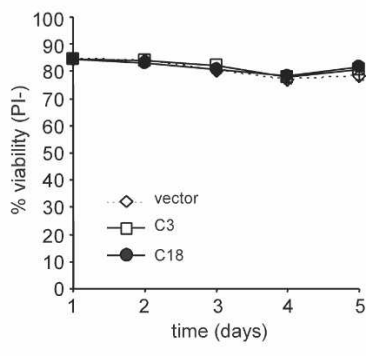

G
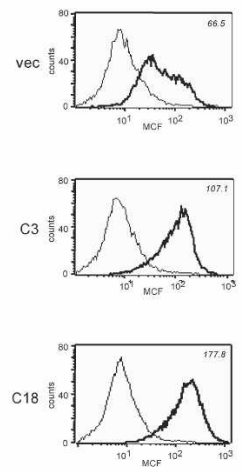

Figure 4. Cells expressing stable shRNA targeting HIF-1 $\alpha$ have impaired survival but enhanced proliferative capacity. $(A)$ Real-time qPCR analysis of Hif- $1 \alpha$ mRNA levels. RNA from cells was isolated and cDNA synthesis was performed as described in the Materials and Methods section. Data are a representative experiment. (B) Western blotting of HIF-1 $\alpha$ and PDK-1 in clones stably expressing shRNA to HIF- $1 \alpha$ after culturing for $4 \mathrm{~h}$ in normoxic $(\mathrm{N})$ or hypoxic $(\mathrm{H})$ conditions. Lysates from vector cells cultured in the presence of IL-3 and exposed to $100 \mu \mathrm{M} \mathrm{CoCl}_{2}$ were used as a positive control. $(C)$ Viability of HIF-1 $\alpha$ knockdown cells grown in the presence of IL-3 cultured under hypoxic condition. At each time point, cells were collected and viable cells were assessed by staining with propidium iodide. Data represent mean of three independent experiments \pm SD. $(D)$ Viability of HIF-1 $\alpha$ knockdown cells grown in the absence of IL-3 cultured under hypoxic condition. At each time point, cells were collected and viable cells assessed by staining with propidium iodide. Data represent mean of three independent experiments \pm SD. (E) Growth curves of IL-3-stimulated cells expressing stable HIF- $1 \alpha$ knockdown cultured under normoxic conditions. Data are a representative experiment performed in triplicate \pm SD. $(F)$ The rate of oxygen consumption under normoxia was measured in HIF-1 $\alpha$ knockdown cells cultured in the presence of IL-3. Data are a representative experiment performed in triplicate \pm SD. $(G)$ Mitochondrial membrane potential was measured in cells cultured in the presence of IL-3 using the potentiometric dye TMRE. The value in the top right corner is a representative value of the mean channel fluorescence (MCF). Unstained cells and stained cells are represented by light and bold histograms, respectively.

time period when compared with control cells (Supplementary Fig. S1).

\section{HIF- $1 \alpha$ deletion versus constitutive HIF-1 $\alpha$ activation has reciprocal effects on cell proliferation}

To eliminate possible off-target effects of shRNA as a cause of the enhanced cell proliferation we observed when HIF- $1 \alpha$ was suppressed, we next determined whether genetic deletion of Hif- $1 \alpha$ would have a similar effect on the proliferative response of primary $\mathrm{T}$ cells. To do this, Hif- $1 \alpha^{f l / f l}$ mice were bred to an inducible UbcCre transgenic mouse to generate $\mathrm{Hif}-1 \alpha^{f l / f l} \mathrm{Cre}^{+}$(Cre) or Hif- $1 \alpha^{f l / f l} \mathrm{Cre}^{-}$(wild-type) control mice (Ryan et al. 1998; Y. Ruzankina, C. Pinzon-Guzman, A. Asare, T. Ong, L. Pontano, V.P. Zediak, M. Velez, A. Bhandoola, and E.J. Brown, in prep.). The nursing mothers were administered tamoxifen $3 \mathrm{~d}$ after birth to activate Cre recombinase in the pups. Primary T cells isolated from the Cre or wild-type control mice were assessed for their ability to proliferate in response to anti-CD3/anti-CD28 stimulation. As seen in Figure 5A, deletion of Hif-1 $\alpha$ in T cells resulted in a dramatic increase in cell accumulation when compared with wild-type controls.

To determine if constitutive activation of HIF- $1 \alpha$ was sufficient to alter cell proliferation under normoxic conditions, two independent NIH3T3 cell lines, C151 and C101, were transfected with a constitutively active form of HIF- $1 \alpha$ under the control of a tetracycline-inducible promoter. In the absence of doxycycline treatment, both C151 and C101 had a similar accumulation in cell number. Doxycycline induction of HIF- $1 \alpha$ expression in both cell lines resulted in a reduction of cell proliferation compared with the uninduced control cells (Fig. 5B).

\section{HIF-1 $\alpha$ impairs cell growth in IL-3-stimulated cells}

To investigate the above issues in greater detail, a more complete analysis of the effect of RNA interference (RNAi) suppression of HIF-1 $\alpha$ on growth factor-depen- 
A

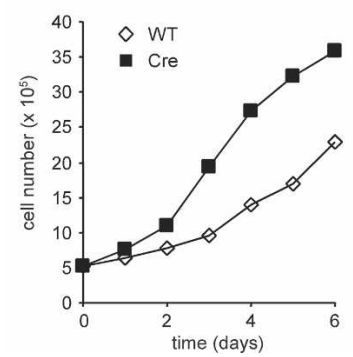

B

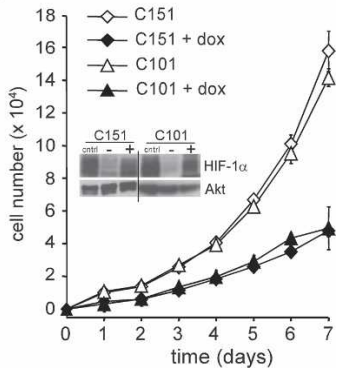

Figure 5. Cellular proliferation is controlled by the levels of HIF-1 $\alpha$. (A) Growth curves of primary T cells isolated from Hif$1 \alpha^{f 1 / f 1} \mathrm{Cre}^{-}$(wild-type [WT]) or Hif- ${ }^{f l / f 1} \mathrm{Cre}^{+}$(Cre) mice that were administered tamoxifen. Two independent experiments were performed and the data presented are one representative experiment. (B) Population doublings (PD) of NIH3T3 cells expressing an inducible form of a constitutively activated HIF- $1 \alpha$. Two independent clones were cultured in the presence or absence of doxycycline. Data are a representative experiment performed in triplicate \pm SD. Inset shows a Western blot of HIF- $1 \alpha$ expression in the transfected cells. Cells were treated with 200 $\mu M$ desferrioxamine (cntrl), or exposed to vehicle control (-), or $0.5 \mu \mathrm{g} / \mathrm{mL}$ doxycycline $(+)$. The doxycycline induction of transfected HIF- $1 \alpha$ is comparable to the level of induction of endogenous HIF- $1 \alpha$ in response to desferrioxamine. Total Akt was used as a loading control.

dent cell survival and proliferation was undertaken. The rate of cell atrophy following growth factor withdrawal was identical in the HIF- $1 \alpha$ shRNA and vector control clones (Fig. 6A). There was also no observable difference in growth factor-independent survival between any of the clones or the parental cells (Fig. 6B; Lum et al. 2005). However, when IL-3 was reintroduced into the culture, the rate of cell growth observed in HIF-1 $\alpha$ shRNA clones was significantly greater than that of the vector controls as demonstrated by the shorter time required for cells expressing HIF-1 $\alpha$ shRNA to increase their cell size (Fig. $6 \mathrm{C})$. The shRNA cells also re-entered growth factorinduced cell division earlier than vector control cells (Fig. 6D). On day 7, the HIF-1 $\alpha$ shRNA cells had expanded 10 -fold whereas control cells were only beginning their first cell division after IL-3 readdition. In the control clones as in the parental cells, both hypoxia- induced HIF- $1 \alpha$ and PDK-1 protein accumulation were first detectable on day 3 after IL-3 addition (Figs. 3, 6E). In contrast, hypoxia-inducible HIF-1 $\alpha$ protein expression was not detectable at any time point tested in HIF- $1 \alpha$ knockdown clones.

\section{Induction of anaerobic glycolysis by HIF-1 $\alpha$ is anti-proliferative}

The suppression of HIF-1 $\alpha$ enhanced growth factor-dependent proliferation and growth. One potential explanation for the observed effects was that HIF- $1 \alpha$ is not a required component of growth factor stimulation of glucose uptake and utilization. Instead, HIF-1 $\alpha$ transcriptional targets regulate the intracellular fate of glucose

(Fig. 7A). By increasing expression of PDK-1 (Kim et al. 2006; Papandreou et al. 2006) and lactate dehydrogenase A (LDH-A) (Semenza et al. 1996), HIF-1 $\alpha$ transcription reprograms the utilization of available glucose into anaerobic metabolism to maintain a high rate of glycolytic ATP production. The induction of LDH-A would promote the efficient recycling of the glycolytic cofactor $\mathrm{NAD}^{+}$. This results in robust and dynamic cytosolic ATP production and can promote cell survival in response to hypoxia or other bioenergetic stresses (Fig. 7A). However, the efficient conversion of pyruvate to lactate and the concomitant induction of PDK-1 by HIF- $1 \alpha$ deprives growing cells of the ability to engage in glucosedependent synthesis of fatty acids, and this suppresses growth. Conversely, when oxygen is abundant, growth factor induction of HIF- $1 \alpha$ is post-translationally repressed to a significant extent, allowing pyruvate and $\mathrm{NADH}$ to be redirected into mitochondrial-dependent lipid synthesis and ATP production respectively, promoting cell growth.

To test this hypothesis, we measured the fate of glucose-derived carbons in growth factor-stimulated control cells as well as cells with suppressed levels of HIF-1 $\alpha$. In normoxia, IL-3-stimulated HIF-1 $\alpha$ shRNA clones had a reduced rate of glycolysis compared with vector controls (Fig. 7B). However, despite the reduced glycolytic rate, the two HIF- $1 \alpha$ clones demonstrated a two- to threefold higher rate of lipid synthesis than control cells (Fig. 7C). When HIF- $1 \alpha$ is suppressed, the cells metabolized less intracellular glucose through the glycolytic pathway and yet a greater proportion of it was diverted into lipid synthesis. The ability to both reduce the rate of glycolysis while increasing lipid synthesis is consistent with the fact that the shRNA clones demonstrate a $>10$-fold reduction in their secretion of lactate in comparison with the control clone.

In the presence of growth factors, HIF- $1 \alpha$ knockdown clones were impaired in their ability to up-regulate glycolysis in response to hypoxia (Fig. 7B). In contrast, the control cells exhibited a threefold increase in glycolysis when exposed to hypoxia. Both the parental (Fig. 1) and control cells experienced a $>50 \%$ decline in glucose-dependent lipid synthesis when exposed to hypoxia (Fig. $7 C)$. In contrast, neither of the HIF- $1 \alpha$ shRNA clones experienced a $>20 \%$ decline in lipid synthesis under conditions of hypoxia. Consistent with a conversion to anaerobic glycolysis, the vector control cells increased their lactate secretion by $>1.5$-fold. There was little to no increase in hypoxia-induced lactate secretion in the $\mathrm{C} 18$ clone (Fig. 7D). The C3 clone expressed low but detectable levels of HIF- $1 \alpha$, secreted an intermediate level of lactate in response to hypoxia.

\section{HIF-1 1 levels regulate intracellular glucose flux}

The change in glucose metabolism was also examined in primary $\mathrm{T}$ cells in which Hif- $1 \alpha$ was deleted by Cremediated recombination and in renal carcinoma cells expressing HIF- $1 \alpha$ shRNA. Similar to the results obtained using the IL-3-dependent cells with HIF-1 $\alpha$ knockdown, 
A

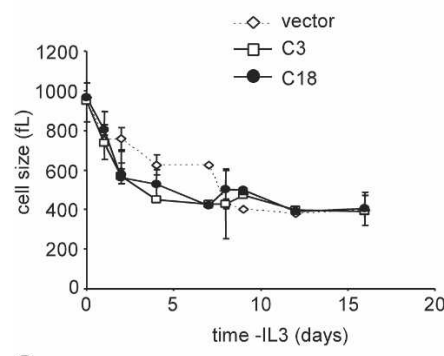

C

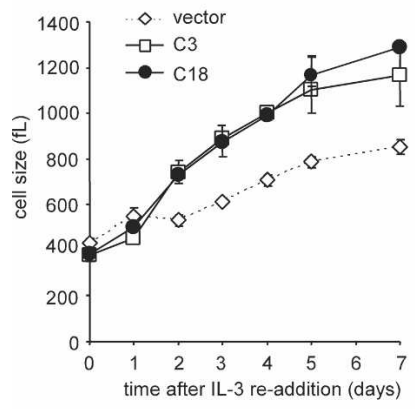

B

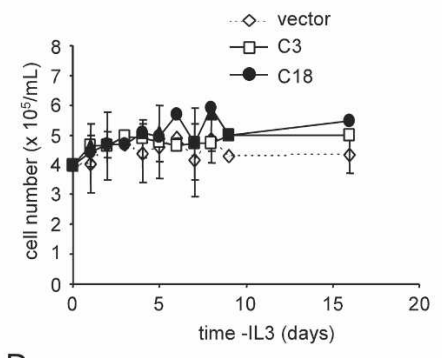

D

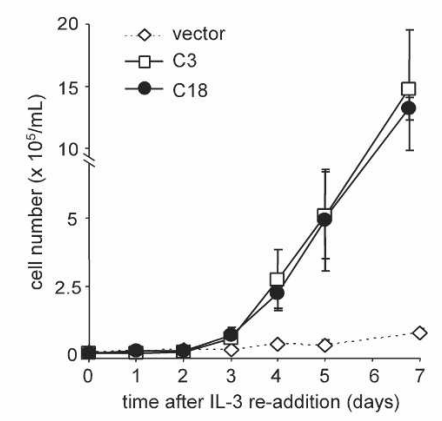

E

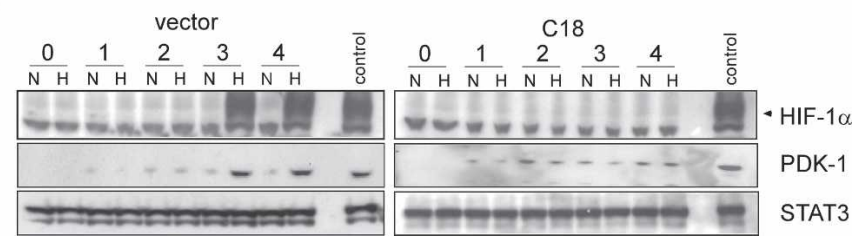

Figure 6. Cell growth and proliferation are enhanced in the absence of HIF-1 $\alpha$. Cells were withdrawn from IL-3 and size $(A)$ and cell number $(B)$ were measured at the indicated time points. On day 16 of withdrawal, cells were restimulated with IL-3 and size $(C)$ and cell number $(D)$ were measured. Data represent the mean of three independent experiments \pm SD. $(E)$ Cells cultured in the absence of IL-3 for $16 \mathrm{~d}$ were placed in fresh complete medium containing IL-3. At the various time points, cells were subjected to an additional $4 \mathrm{~h}$ of culture under $21 \% \mathrm{O}_{2}(\mathrm{~N})$ or $1.5 \% \mathrm{O}_{2}(\mathrm{H})$. Cell lysates were analyzed by Western blot for HIF- $1 \alpha$ and PDK-1 expression. A representative vector control and a HIF- $1 \alpha$ cell line (C18) expressing a stable HIF-1 $\alpha$ shRNA are shown. STAT3 was used as a loading control. Cells cultured in the presence of IL-3 and exposed to hypoxia were used as a positive control.
anti-CD3/anti-CD28-activated HIF- $1 \alpha$-deleted primary $\mathrm{T}$ cells displayed a decrease in lactate production under normoxic conditions (Fig. 8A). Despite the lower levels of glucose consumed, a fourfold increase in the rate of lipid synthesis was observed in cells that had genetic deletion of Hif-1 $\alpha$ when compared with wild-type activated T cells (Fig. 8B). The enhanced synthesis of lipids in Hif-1 $\alpha$-deficient cells was not due to the activity of the glucose sensing transcription factor ChREBP that has been implicated in the regulation of glucose to lipid metabolism in the liver, as its expression was undetectable in resting or activated lymphocytes (Supplementary Fig. S2). Consistent with a reduced rate of anaerobic glycolysis and enhanced glucose-dependent lipid synthesis, cells lacking HIF-1 $\alpha$ secreted a lower level of lactate into the cell culture medium (Fig. 8C).

Hif-1 $\alpha$-deficient and wild-type $\mathrm{T}$ cells were also cultured under hypoxic conditions. Exposure of wild-type T cells to hypoxia resulted in an increase in glucose consumption. However, T cells lacking HIF-1 $\alpha$ expression failed to up-regulate the consumption of glucose from the cell culture medium in response to hypoxia (Fig. 8A). The glucose-dependent lipid synthesis following exposure to hypoxia decreased in both wild-type and Hif-1 $\alpha$ deleted $\mathrm{T}$ cells although there remained substantial differences in the lipid synthesis rate even in hypoxia (Fig. 8B). As shown in Figure 8C when compared with wild- type controls, activated $\mathrm{T}$ cells lacking HIF-1 $\alpha$ failed to further increase the production of lactate when exposed to hypoxia.

To determine whether the effect of HIF-1 $\alpha$ on glucose metabolism was unique to hematopoietic cells, glucose metabolism was also assessed in renal carcinoma cell lines with stable suppression of HIF-1 $\alpha$. Under normoxia, the level of glucose consumed in two independent cell lines expressing shRNA to HIF- $1 \alpha$ was reduced compared with controls (Supplementary Fig. S1B). However, compared with controls both knockdown clones displayed an eightfold increase in lipid synthesis and a lower level of lactate secretion into the culture medium (Supplementary Fig. S1C,D).

In contrast to cells with suppressed levels of HIF-1 $\alpha$, a different pattern of glucose metabolism was seen in cells that ectopically expressed HIF-1 $\alpha$. Two inducible clones were generated to express a constitutively active form of HIF-1 $\alpha$. In the absence of induction, clone C151 and C101 consumed similar levels of glucose from the culture medium (Supplementary Fig. S3A). However, doxycycline-induced HIF- $1 \alpha$ in both cell lines resulted in a dramatic increase in glucose consumption. Despite the higher glucose utilization, doxycycline induction of HIF$1 \alpha$ reduced the conversion of carbons into lipids when compared with uninduced controls (Supplementary Fig. S3B). The decreased diversion of glycolytic intermediates 
Lum et al.

A

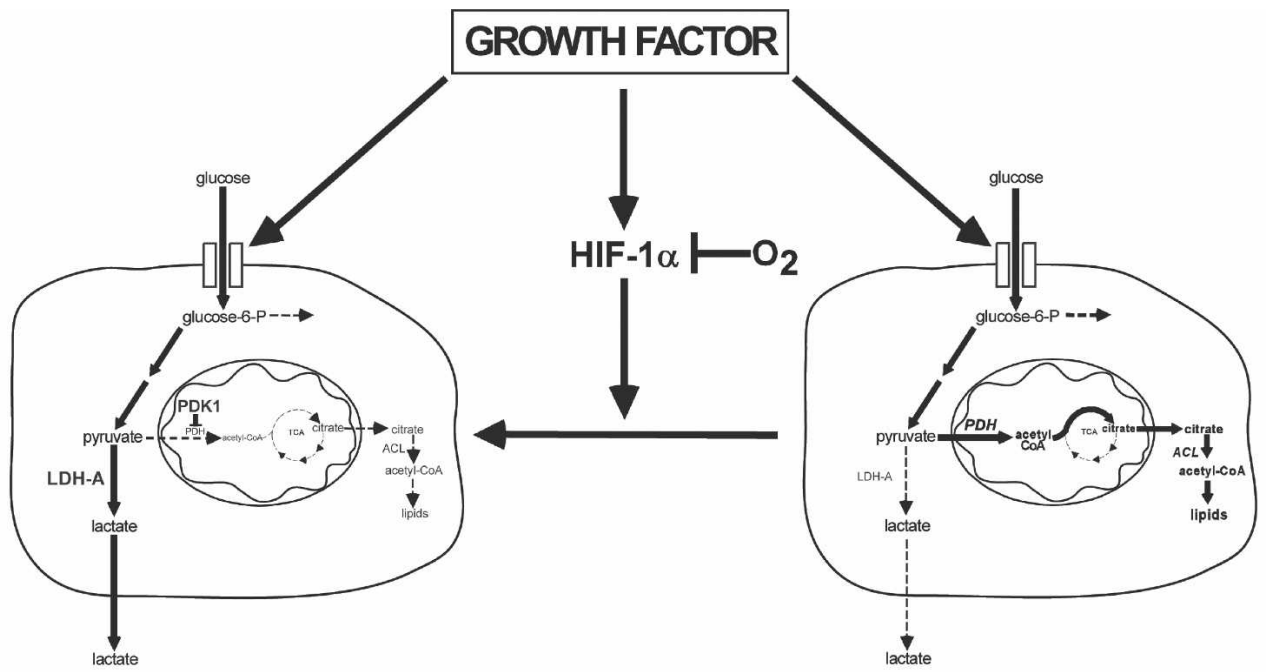

Cell Survival

Cell Growth

B

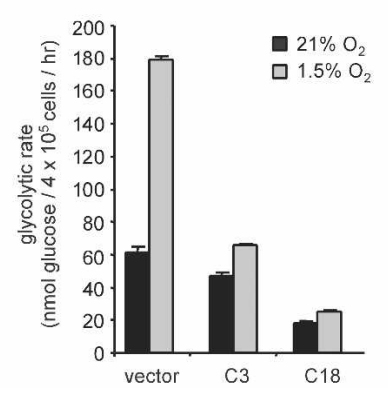

C

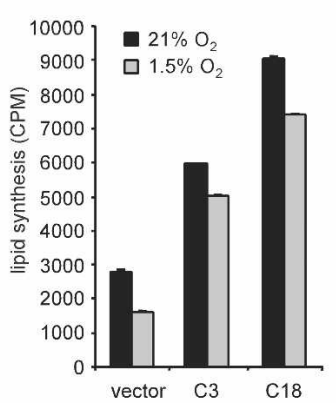

$\mathrm{D}$

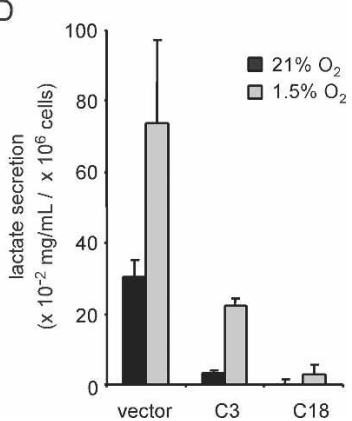

Figure 7. Induction of glycolysis through HIF-1 $\alpha$ is anti-proliferative. $(A)$ Growth factors stimulate cellular glucose uptake and the expression of HIF-1 $\alpha$. Under conditions of normoxia, the accumulation of HIF- $1 \alpha$ is repressed by $\mathrm{O}_{2}$-dependent hydroxylation and degradation of the HIF- $1 \alpha$ protein. When HIF- $1 \alpha$ is repressed by $\mathrm{O}_{2}$-dependent degradation and/or HIF- $1 \alpha$ shRNA, glycolytic pyruvate is diverted into mitochondrial-dependent lipid synthesis. Pyruvate is catabolized by mitochondrial PDH into acetyl-CoA, which is used in the TCA cycle to produce citrate that is transported into the cytosol, where it acts as a further regulator of glucose-6-P metabolism. Citrate is metabolized to produce acetyl-CoA by the enzyme ATP-citrate lyase (ACL) to supply the cell with a source of acetyl-CoA for lipid synthesis. When HIF- $1 \alpha$ is stabilized by mitochondrial ROS or oxygen deprivation, the increased HIF- $1 \alpha$-dependent transcription can result in a metabolic reprogramming of intracellular glucose fate. The HIF-1 $\alpha$-dependent increases in glycolytic genes including $L d h-A$ lead to an enhanced rate of anaerobic glycolysis, and the induction of mitochondrial regulatory enzymes such as PDK-1 decrease pyruvate metabolism in the mitochondria, resulting in decreased mitochondrial TCA cycle activity and cytosolic citrate levels. These effects would support non-oxygen-dependent ATP production by degradation of glucose to lactate, and suppress mitochondrial activity and cytosolic lipid synthesis. (B) Glycolytic rate of cells cultured in the presence of IL-3 following $24 \mathrm{~h}$ incubation under $21 \% \mathrm{O}_{2}$ or $1.5 \% \mathrm{O}_{2}$. In the absence of IL-3 (not shown), glycolysis was reduced $<6.58$ nmol of glucose per hour in both the vector controls and HIF- $1 \alpha$ shRNA cells. Data are the mean of three independent experiments \pm SD performed in triplicate. (C) Cells cultured in the presence of IL-3 were subjected to $4 \mathrm{~h}$ of $21 \% \mathrm{O}_{2}$ or $1.5 \% \mathrm{O}_{2}$ followed by an additional $20-24 \mathrm{~h}$ incubation with ${ }^{14} \mathrm{C}$-labeled pyruvate. Lipids were extracted from cell lysates and total incorporation of ${ }^{14} \mathrm{C}$-labeled lipid was measured by scintillation counting. Data are a representative experiment \pm SD for triplicate samples. $(D)$ Accumulation of lactate in cell culture supernatants. Cells were cultured in $1 \mathrm{~mL}$ of medium for $5 \mathrm{~d}$ in the presence of IL-3 and subjected to $1.5 \% \mathrm{O}_{2}$ for an additional $24 \mathrm{~h}$. Lactate levels in supernatants were measured as described in Materials and Methods. Data represent three independent experiments \pm SD.

into lipid synthesis in the HIF- $1 \alpha$-expressing clones resulted in a greater production of lactate (Supplementary Fig. S3C).

\section{Discussion}

The above results challenge the prevailing belief that the transcription factor HIF- $1 \alpha$ is a cell-intrinsic regulator of glycolysis (Semenza et al. 1996; Seagroves et al. 2001; Pouyssegur et al. 2006). The data demonstrate that in hematopoietic cells growth factor-dependent signal transduction is required to accumulate Hif- $1 \alpha$ mRNA. Furthermore, the data support that HIF- $1 \alpha$ is a critical component of IL-3 regulation of cell metabolism even under normoxic conditions. Although a cell's expression of Hif- $1 \alpha$ mRNA is growth factor dependent, the data 
A

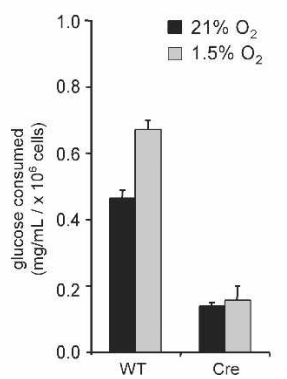

B

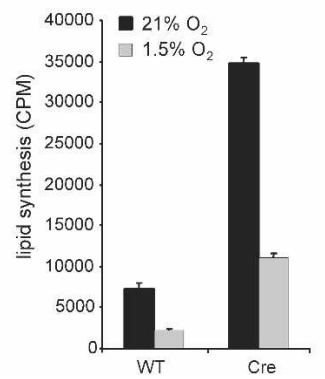

C

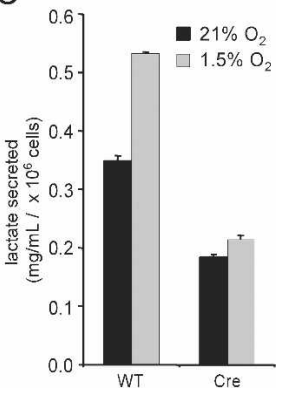

Figure 8. Glucose utilization in primary $\mathrm{T}$ cells is impaired by HIF- $1 \alpha$. (A) Glucose consumption in primary $\mathrm{T}$ cells isolated from Hif-1 ${ }^{f l / f 1} \mathrm{Cre}^{-}$(wild-type [WT]) or $\mathrm{Hif}_{-1}{ }^{f l / f 1} \mathrm{Cre}^{+}$(Cre) mice that were administered tamoxifen. $\mathrm{T}$ cells were stimulated under $21 \%$ or $1.5 \%$ oxygen by plate-bound anti-CD3/anti-CD28 in 1-mL cell cultures, and supernatants were collected $48 \mathrm{~h}$ poststimulation for glucose analysis. Data are a representative experiment performed in triplicate \pm SD. $(B)$ Cells were activated by plate-bound anti-CD3/anti-CD28 for $2 \mathrm{~d}$

followed by addition of ${ }^{14} \mathrm{C}$-labeled pyruvate under normoxic or hypoxic conditions. Cells were cultured for an additional $2 \mathrm{~d}$ in the presence of IL-2. Lipids were extracted from cell lysates and total incorporation of ${ }^{14} \mathrm{C}$-labeled lipid was measured by scintillation counting. Data are a representative experiment \pm SD for triplicate samples. $(C)$ Cells were cultured under identical conditions described in $A$ and the amount of secreted lactate into $1 \mathrm{~mL}$ of culture medium was measured as described in Materials and Methods. Data are a representative experiment \pm SD.

are consistent with previous observations that the expression of HIF-1 $\alpha$ protein is post-translationally repressed by enzyme-dependent hydroxylation of proline residues in the presence of oxygen and $\alpha$-ketoglutarate through pVHL-dependent proteasomal degradation (Maxwell et al. 1999). HIF-1 $\alpha$ is not a simple transcriptional inducer of glycolytic genes, but instead reprograms the fate of intracellular glucose. This is consistent with observations demonstrating the recovery of glucose uptake occurs prior to the recovery of inducible HIF- $1 \alpha$ protein expression during growth factor restimulation (Fig. 3) and that T cells lacking HIF-1 $\alpha$ engage glucose uptake and glucose-dependent lipid synthesis following mitogenic stimulation.

One reason that these normoxic effects of HIF-1 $\alpha$ have not been previously appreciated is that they occur at levels of HIF- $1 \alpha$ protein that are at or below the levels of standard protein quantitation by Western blotting. However, two independent techniques for genetic elimination of HIF-1 $\alpha$ expression suggest that even low to undetectable levels of the protein have profound effects on the regulation of intracellular glucose metabolism. Since HIF does not appear to be required for growth factordeprived cells to survive hypoxia, it appears that the induction of anaerobic glycolysis is not a sufficient explanation for HIF- $1 \alpha$ 's ability to promote the survival of growing cells under conditions of hypoxia. HIF-1 $\alpha$-dependent metabolic reprogramming directs glucose away from synthetic pathways, allowing the cell to decrease its ATP consumption, and into anaerobic glycolysis to increase ATP production.

The ability of HIF- $1 \alpha$ to suppress normoxic cell growth and proliferation at first seems paradoxical. However, the ability of cells to generate sufficient cytosolic acetylCoA to support the lipid synthesis of membranes depends on mitochondrial pyruvate dehydrogenase ( $\mathrm{PDH})$ converting pyruvate into acetyl-CoA. The ability of pyruvate to enter the TCA cycle in the mitochondria is regulated by PDK-1. PDK-1 activity is primarily determined by its level of expression, which has recently been shown to be under the transcriptional control of HIF-1 $\alpha$ (Figs. 2, 3, 4, 6; Kim et al. 2006; Papandreou et al. 2006).
When expressed, PDK-1 suppresses the activity of PDH and limits the influx of pyruvate into the TCA cycle. As pyruvate entry into the TCA cycle is suppressed there will be a concomitant decline in the production of citrate. In growing cells, the citrate exported from mitochondria into the cytosol suppresses glycolysis at the level of phosphofructose kinase 1 (PFK-1). This partial suppression of PFK-1 may be adaptive for cell growth by allowing a greater amount of glucose-6-phosphate to be diverted into nucleotide biosynthesis and glycosylation reactions. Furthermore, the cytosolic degradation of citrate provides the major source of acetyl-CoA for lipid and isoprenoid synthesis during cell growth. Therefore, HIF$1 \alpha$ enhanced PDK-1 activity results in a decline in mitochondrial citrate production, resulting in a derepression of PFK-1 activity and a concomitant suppression of lipid synthesis.

Another well-characterized transcriptional target of HIF-1 $\alpha$ is Ldh-A (Firth et al. 1995; Semenza et al. 1996). In contrast to LDH-B, LDH-A enzymatically favors production of lactate from pyruvate. As LDH-A levels increase, cellular pyruvate is converted preferentially to lactate and secreted into the extracellular space (Fantin et al. 2006). Thus, HIF-1 $\alpha$ transcription reprograms the intracellular utilization of glucose from its use in lipid and nucleotide synthesis and redirects glucose almost exclusively into anaerobic glycolysis to support cellular ATP production.

Growth factor-dependent induction of HIF-1 $\alpha$ appears to partially contribute to the ability of growth factors and oncogenic mutations in the PI3K/Akt signal transduction pathway to induce a metabolic conversion to aerobic glycolysis (Warburg Effect). Even under conditions of normoxia, HIF- $1 \alpha$-induced metabolic reprogramming may prevent growth factor- or oncogene-directed excesses in glucose uptake from generating damaging levels of mitochondrial ROS. Several groups have demonstrated that mitochondrial ROS are an independent regulator of HIF-1 $\alpha$ activity (Brunelle et al. 2005; Guzy et al. 2005; Mansfield et al. 2005). This is consistent with a higher level of mitochondrial membrane potential observed when HIF-1 $\alpha$ is suppressed (Fig. 4G) and may ex- 
plain why cells lacking HIF-1 $\alpha$ undergo premature senescence (Welford et al. 2006). However, ROS activation of HIF- $1 \alpha$ transcription would lead to a diversion of glucose away from mitochondria and into lactate production, allowing cells to eliminate excess carbon being taken up as a consequence of growth factor- or oncogene-dependent signaling.

Hematopoietic cells appear to lack the cell intrinsic ability to take up sufficient extracellular nutrients to maintain ATP production and macromolecular synthesis (Vander Heiden et al. 2001; Bentley et al. 2003). Under conditions of growth factor deprivation, hematopoietic cells turn to macroautophagy to maintain cellular bioenergetics (Lum et al. 2005). Constitutive HIF-1 $\alpha$ expression in growth factor-deprived cells would seem to be disadvantageous to their survival, since the continuous transcription, translation, and degradation of HIF- $1 \alpha$ is a highly ATP-dependent process. Under these conditions, global protein synthesis decreases and transcription becomes repressed, limiting consumption of existing energy stores.

The present results help to clarify this paradox by demonstrating that Hif- $1 \alpha$ mRNA accumulation is regulated by growth factor-dependent signal transduction. Furthermore, HIF-1 $\alpha$ is not required for growth factordeprived cells to survive hypoxia. This is consistent with the fact that these cells have a limited ability to take up extracellular glucose, and therefore modulation of intracellular glucose metabolism is unlikely to have a significant impact on the ability of cells to maintain cell survival when oxygen becomes limiting. Anaerobic glycolysis is an effective hypoxia survival strategy only under conditions of high intracellular glucose availability.

The present study suggests that HIF-1 $\alpha$, the HIF isoform selectively expressed in hematopoietic cells, through effects on cellular metabolism acts to limit cell growth and proliferation under normoxic conditions. Earlier studies have reported that Hif-1 $\alpha$ deficiency has only a limited effect on the proliferation of embryonic stem (ES) cells (Carmeliet et al. 1998; Iyer et al. 1998; Ryan et al. 1998). However, it is unclear from those studies if glucose metabolism was affected by the loss of HIF- $1 \alpha$ and whether ES cells have a similar dependence on intracellular glucose utilization compared with hematopoietic cells used here. Our studies demonstrate HIF- $1 \alpha$ is both necessary and sufficient to mediate the changes in glucose metabolism and its effects on cell growth and proliferation. Consistent with this conclusion, cells expressing a constitutively active form of HIF$1 \alpha$ lacking the oxygen-dependent degradation domain have reduced accumulation in cell number (Fig. 5B) and have been reported to undergo cell cycle arrest (Koshiji et al. 2004). These data, at first glance, appear contradictory to existing views of the role of HIF- $1 \alpha$ in oncogenic transformation (Zhong et al. 1999; Ryan et al. 2000; Semenza 2003). The results may explain why patients with von Hippel-Lindau Syndrome display a limited spectrum of tumors. von Hippel-Lindau tumors lack the E3 ubiquitin ligase pVHL required for the degradation of HIF-1, leading to constitutive HIF-1 stabilization. However, the tumor spectrum observed in these patients is primarily restricted to cell types that express HIF- $2 \alpha$ in addition to HIF-1 $\alpha$. Recent transcriptional array studies suggested that HIF- $2 \alpha$ transcriptional targets are distinct from those of HIF- $1 \alpha$ and that HIF- $2 \alpha$ induces nonglycolytic responses that are distinct from those mediated by HIF$1 \alpha$ (Hu et al. 2003; V. Wang et al. 2005). Thus, HIF- $1 \alpha$ activity may not be sufficient for tumorigenesis in cells lacking pVHL.

In summary, the data support the hypothesis that HIF$1 \alpha$ is not a cell-intrinsic regulator of glucose metabolism but instead is a growth factor-dependent modulator of intracellular glucose utilization. By dynamically partitioning the growth factor-stimulated glucose uptake between synthetic pathways and anaerobic glycolysis, HIF$1 \alpha$ endows growing cells with the ability to adapt to changes in oxygen availability and/or ROS stress. HIF's evolution as a critical component of growth factor regulation of cell survival may explain why it is not observed in single cell eukaryotes despite its well-characterized role in mammalian tissues.

\section{Materials and methods}

Cell lines, culture, and reagents

Cell culture experiments were performed with IL-3-dependent $b_{a x}^{-1-} b_{a k}^{-/-}$cells (Lum et al. 2005) in complete medium consisting of RPMI 1640, 10\% heat-inactivated fetal bovine serum (Gemini), $10 \mathrm{U} / \mathrm{mL}$ penicillin/streptomycin, $2 \mathrm{mM}$ L-glutamine, $50 \mu \mathrm{M} \beta$-mercaptoethanol, and $10 \mathrm{mM}$ HEPES. For experiments performed in the presence of IL-3, complete medium was supplemented with $3.5 \mathrm{ng} / \mathrm{mL}$ recombinant mouse IL-3 (BD Pharmingen). For experiments performed in the absence of IL-3, cells were washed three times in complete medium without IL-3 or serum and resuspended in complete medium without IL-3. All cell culture reagents were purchased from Invitrogen unless stated otherwise. NIH3T3-inducible Tet-on cells were generated by stable introduction of pTet-on (Clontech) and pTre-HIF-1 $\alpha$-DPA vectors as previously described (Hu et al. 2003). Cells were maintained in DMEM with $10 \%$ FBS (Clontech Tet-approved) with $1 \%$ penicillin/streptomycin, L-glutamine, and nonessential amino acids with 150 $\mu \mathrm{g} / \mathrm{mL}$ each neomycin and hygromycin.

\section{Oxygen deprivation, transfections, and RNAi}

To induce HIF- $1 \alpha$ protein expression, cells were treated with $100 \mu \mathrm{M}$ cobalt chloride $\left(\mathrm{CoCl}_{2}\right)$ for $4-24 \mathrm{~h}$. For hypoxia $(1.5 \%$ $\mathrm{O}_{2}$ ), cells were cultured in an $\mathrm{InVivo}_{2}$ hypoxic work station (Biotrace, Inc.) for 4-72 h. shRNA targeting murine HIF-1 $\alpha$ (GA ACTAACTGGACACAGTGTGTT) was excised from pBabepuro with BamHI and SalI followed by ligation into pKD-GFP as previously described (Lum et al. 2005). Transfection of shRNA into $\mathrm{bax}^{-1-} \mathrm{bak}^{-/-}$cells was performed by Nucleofector transfection (Amaxa) using program T20 with $8 \mu$ of DNA per $2.0 \times 10^{6}$ cells. Two days to $4 \mathrm{~d}$ post-transfection, GFP-positive cells were FACS-sorted. Individual clones stably expressing the shRNA were generated by single-cell sorting into 96 round-bottom wells and Western blot analysis was used to select clones with stable knockdown of HIF-1 $\alpha$. Renal cell carcinoma cells (RCC-4) with HIF- $1 \alpha$ knockdown were generated using the same shRNA construct described above. Briefly, the shRNA plasmid or a vec- 
tor control was stably introduced into PT67 packaging cells (Clontech) and viral supernatants were used to transduce RCC-4 cells. Two stable HIF-1 $\alpha$ knockdown clones (hp1 and hp2) and one control (vec) were generated and selected for further analysis.

Hif- $1 \alpha^{f 1 / f 1} \mathrm{Cre}^{+}$mice and primary lymphocyte experiments

$H i f-1 \alpha^{f 1 / f 1}$ mice were mated with Ubiquitin C-Cre (Ubc-Cre) mice to obtain $\mathrm{Hif}-1 \alpha^{f 1 / f 1} \mathrm{Cre}^{-}$(wild type) or $\mathrm{Hif}-1 \alpha^{f 1 / f 1} \mathrm{Cre}^{+}$(Cre). Generation and genotyping for Hif-1 $\alpha$ and Ubc-Cre have been described elsewhere (Y. Ruzankina, C. Pinzon-Guzman, A. Asare, T. Ong, L. Pontano, V.P. Zediak, M. Velez, A. Bhandoola, and E.J. Brown, in prep.). Nursing mothers of $\mathrm{Hif}-1 \alpha^{f 1 / f 1} \mathrm{Cre}^{+}$ mice were administered $6 \mathrm{mg}$ of tamoxifen free base (MP Biomedicals) once a day, four times within $1 \mathrm{wk}$, starting $3 \mathrm{~d}$ after birth to activate Cre recombinase in $\mathrm{Hif}-1 \alpha^{f 1 / f 1} \mathrm{Cre}^{+}$pups. $H$ if- $1 \alpha^{f 1 / f 1} \mathrm{Cre}^{-}$littermates treated with tamoxifen were used as controls. PCR genotyping at weaning showed at least $90 \%$ deletion efficiency of $\mathrm{Hif}-1 \alpha$ in $\mathrm{Cre}^{+}$animals. For isolation of $\mathrm{T}$ cells, lymph nodes were collected in ice-cold Hanks Basic Salt Solution from both groups of mice. T cells were obtained by negative selection as previously described (Deberardinis et al. 2006). After enrichment, lymphocytes were seeded into wells that were pretreated with $1 \mu \mathrm{g} / \mathrm{mL}$ each plate-bound anti-CD3 (Ebioscience) and anti-CD28 (BD Pharmingen). After $2 \mathrm{~d}$ of culture, cells were supplemented with $50 \mathrm{U} / \mathrm{mL}$ mouse recombinant IL-2 (PeproTech).

\section{Reporter assay}

The HIF- $1 \alpha$ reporter construct (HIF- $1 \alpha$ response element [HRE]luciferase reporter) was used as previously described (Arsham et al. 2002). Briefly, $8 \mu \mathrm{g}$ of HIF-1 $\alpha$ reporter DNA and $1.2 \mu \mathrm{g}$ of pRLTK were cotransfected using Nucleofector V solution and program T20 (Amaxa) into $2.0 \times 10^{6}$ cells. Ten hours after transfection, cells were cultured in hypoxia $\left(1.5 \% \mathrm{O}_{2}\right)$ or normoxia $\left(21 \% \mathrm{O}_{2}\right)$ for an additional $24 \mathrm{~h}$. Luciferase activity assay was performed using Dual-Glo Luciferase Assay System (Promega) according to instructions provided and measured on a TR717 Luminometer (Tropix).

\section{Mitochondrial function}

The rate of oxygen consumption was measured using a waterjacketed, air tight oxymeter (Hansatech). Cells $\left(2.5 \times 10^{6}\right)$ were resuspended in $0.25 \mathrm{~mL}$ of culture medium containing IL-3. To assess mitochondrial membrane potential, cells were incubated for $20 \mathrm{~min}$ with $50 \mathrm{nM}$ tetramethylrhodamine ethyl ester (TMRE) followed by flow cytometric analysis.

\section{qPCR, immunoblotting, and glycolysis}

Total RNA was isolated from growth factor-stimulated cells that were cultured under normoxia using TRIzol Reagent (Invitrogen). One microgram of RNA was used to prepare cDNA using SuperScript II Reverse Transcriptase (Invitrogen) according to the manufacturer's instructions. All samples were normalized to STAT3 transcript levels. Murine HIF-1 $\alpha$, GLUT1, and STAT3 probes were purchased from Applied Biosystems. Samples were run on a $7900 \mathrm{HT}$ Sequence Detection System (Applied Biosystems) and analyzed using SDS 2.1. Standard deviations were calculated using the formula $\left[(R Q)\left(\Delta C_{t} S D\right) /\right.$ average $\Delta \mathrm{C}_{\mathrm{t}}$ ]. For lysates, cells were lysed in RIPA buffer $(50 \mathrm{mM}$ Tris- $\mathrm{HCl}$ at $\mathrm{pH} 7.4,150 \mathrm{mM} \mathrm{NaCl}, 1 \mathrm{mM}$ PMSF, $1 \%$ Triton $\mathrm{X}-100,1 \%$ sodium deoxycholate, $0.1 \%$ SDS, two Complete EDTA-free protease inhibitor cocktail tablets [Roche Applied Science]/10 mL RIPA) and cleared lysates were separated on
$4 \%-8 \%$ TRIS-Acetate gels or $4 \%-12 \%$ TRIS-Bis gels (Invitrogen) followed by transfer onto nitrocellulose. After blocking in $5 \%$ skim milk, blots were probed using anti-HIF-1 $\alpha$ (1:1000), anti-PDK-1 (Stressgen) or anti-STAT3 (1:2500; Cell Signaling Technologies \#9132). Glycolysis experiments were performed as previously described (Lum et al. 2005).

\section{Lipid synthesis}

Cells were cultured under normoxic or hypoxic conditions for $16 \mathrm{~h}$ followed by incubation with $2-{ }^{14} \mathrm{C}$ pyruvic acid sodium salt or D-[U- $\left.{ }^{14} \mathrm{C}_{6}\right]$ glucose (Perkin Elmer) as indicated. After an additional 20-24 h of incubation, $2 \times 10^{6}$ cells were collected in triplicate. Cells were spun down and wash three times in $1 \times$ PBS followed by lysis with $0.5 \%$ Triton X-100, vortexing, and the addition of $2 \mathrm{~mL}$ methanol. Lysates were extracted by adding each of the following in succession with vortexing: $1 \mathrm{~mL}$ $\mathrm{CHCl}_{3}, 1 \mathrm{~mL} \mathrm{CHCl}_{3}$, and $1 \mathrm{~mL} \mathrm{H}_{2} \mathrm{O}$. Lysates were spun at 2000 rpm for $5 \mathrm{~min}$ and the lower organic phase was transferred into a new tube. The organic phase was evaporated under nitrogen stream and lipid fraction was resuspended in $50 \mu \mathrm{L} \mathrm{CHCl}_{3}$. Lipids were spotted on chromatography filter paper (Varian), allowed to dry, placed into scintillation vials containing $2.5 \mathrm{~mL}$ of EcoLume (ICN Radiochemicals), and counted on a 1450 Microbeta Jet scintillation counter (Wallac).

\section{Glucose and lactate measurements}

Cells were cultured under continuous normoxic or hypoxic conditions and supernatants were collected and frozen at $-20^{\circ} \mathrm{C}$. Lactate levels were quantified by colorimetric assay (CMA 600 Microdialysis) as per the manufacturer's instructions. Two microliters of supernatant were used in each assay performed in triplicate. Glucose consumption assay was performed using glucose reagent (CMA Microdialysis $\mathrm{AB}$ ) as previously described (Frauwirth et al. 2002).

\section{Acknowledgments}

We thank Kyle Mansfield, Xuemei Tong, and other members of the Simon and Thompson laboratory for help in conducting experiments or careful critique of the manuscript. We also thank Niklas Thompson for assistance with the graphical artwork. J.J.L is supported by a Leukemia and Lymphoma Society Fellowship Award and R.J.D. is suppported by a grant from the $\mathrm{NIH}$. This work was supported in part by grants from the NCI and NIH.

\section{References}

Arsham, A.M., Plas, D.R., Thompson, C.B., and Simon, M.C. 2002. Phosphatidylinositol 3-kinase/Akt signaling is neither required for hypoxic stabilization of HIF-1 $\alpha$ nor sufficient for HIF-1-dependent target gene transcription. J. Biol. Chem. 277: 15162-15170.

Bardos, J.I., Chau, N.M., and Ashcroft, M. 2004. Growth factormediated induction of HDM2 positively regulates hypoxiainducible factor $1 \alpha$ expression. Mol. Cell. Biol. 24: 29052914.

Bauer, D.E., Harris, M.H., Plas, D.R., Lum, J.J., Hammerman, P.S., Rathmell, J.C., Riley, J.L., and Thompson, C.B. 2004. Cytokine stimulation of aerobic glycolysis in hematopoietic cells exceeds proliferative demand. FASEB J. 18: 1303-1305.

Bentley, J., Itchayanan, D., Barnes, K., McIntosh, E., Tang, X., Downes, C.P., Holman, G.D., Whetton, A.D., Owen-Lynch, 
P.J., and Baldwin, S.A. 2003. Interleukin-3-mediated cell survival signals include phosphatidylinositol 3-kinase-dependent translocation of the glucose transporter GLUT1 to the cell surface. J. Biol. Chem. 278: 39337-39348.

Blum, R., Jacob-Hirsch, J., Amariglio, N., Rechavi, G., and Kloog, Y. 2005. Ras inhibition in glioblastoma downregulates hypoxia-inducible factor- $1 \alpha$, causing glycolysis shutdown and cell death. Cancer Res. 65: 999-1006.

Brand, K. 1985. Glutamine and glucose metabolism during thymocyte proliferation. Pathways of glutamine and glutamate metabolism. Biochem. J. 228: 353-361.

Brunelle, J.K., Bell, E.L., Quesada, N.M., Vercauteren, K., Tiranti, V., Zeviani, M., Scarpulla, R.C., and Chandel, N.S. 2005. Oxygen sensing requires mitochondrial ROS but not oxidative phosphorylation. Cell Metab. 1: 409-414.

Bui, T. and Thompson, C.B. 2006. Cancer's sweet tooth. Cancer Cell 9: 419-420.

Carmeliet, P., Dor, Y., Herbert, J.M., Fukumura, D., Brusselmans, K., Dewerchin, M., Neeman, M., Bono, F., Abramovitch, R., Maxwell, P., et al. 1998. Role of HIF-1 $\alpha$ in hypoxiamediated apoptosis, cell proliferation and tumour angiogenesis. Nature 394: 485-490.

Deberardinis, R.J., Lum, J.J., and Thompson, C.B. 2006. Phosphatidylinositol 3-kinase-dependent modulation of carnitine palmitoyltransferase $1 \mathrm{~A}$ expression regulates lipid metabolism during hematopoietic cell growth. J. Biol. Chem. 281: 37372-37380.

Fantin, V.R., St-Pierre, J., and Leder, P. 2006. Attenuation of LDH-A expression uncovers a link between glycolysis, mitochondrial physiology, and tumor maintenance. Cancer Cell 9: 425-434.

Firth, J.D., Ebert, B.L., and Ratcliffe, P.J. 1995. Hypoxic regulation of lactate dehydrogenase A. Interaction between hypoxia-inducible factor 1 and cAMP response elements. I. Biol. Chem. 270: 21021-21027.

Frauwirth, K.A., Riley, J.L., Harris, M.H., Parry, R.V., Rathmell, J.C., Plas, D.R., Elstrom, R.L., June, C.H., and Thompson, C.B. 2002. The CD28 signaling pathway regulates glucose metabolism. Immunity 16: 769-777.

Fukuda, R., Hirota, K., Fan, F., Jung, Y.D., Ellis, L.M., and Semenza, G.L. 2002. Insulin-like growth factor 1 induces hypoxia-inducible factor 1-mediated vascular endothelial growth factor expression, which is dependent on MAP kinase and phosphatidylinositol 3-kinase signaling in colon cancer cells. J. Biol. Chem. 277: 38205-38211.

Guzy, R.D., Hoyos, B., Robin, E., Chen, H., Liu, L., Mansfield, K.D., Simon, M.C., Hammerling, U., and Schumacker, P.T. 2005. Mitochondrial complex III is required for hypoxiainduced ROS production and cellular oxygen sensing. Cell Metab. 1: 401-408.

Hatzivassiliou, G., Zhao, F., Bauer, D.E., Andreadis, C., Shaw, A.N., Dhanak, D., Hingorani, S.R., Tuveson, D.A., and Thompson, C.B. 2005. ATP citrate lyase inhibition can suppress tumor cell growth. Cancer Cell 8: 311-321.

Hu, C.J., Wang, L.Y., Chodosh, L.A., Keith, B., and Simon, M.C. 2003. Differential roles of hypoxia-inducible factor $1 \alpha$ (HIF$1 \alpha)$ and HIF- $2 \alpha$ in hypoxic gene regulation. Mol. Cell. Biol. 23: 9361-9374.

Isaacs, J.S., Jung, Y.J., Mimnaugh, E.G., Martinez, A., Cuttitta, F., and Neckers, L.M. 2002. Hsp90 regulates a von Hippel Lindau-independent hypoxia-inducible factor- $1 \alpha$-degradative pathway. J. Biol. Chem. 277: 29936-29944.

Isaacs, J.S., Jung, Y.J., Mole, D.R., Lee, S., Torres-Cabala, C., Chung, Y.L., Merino, M., Trepel, J., Zbar, B., Toro, J., et al. 2005. HIF overexpression correlates with biallelic loss of fumarate hydratase in renal cancer: Novel role of fumarate in regulation of HIF stability. Cancer Cell 8: 143-153.

Iyer, N.V., Kotch, L.E., Agani, F., Leung, S.W., Laughner, E., Wenger, R.H., Gassmann, M., Gearhart, J.D., Lawler, A.M., Yu, A.Y., et al. 1998. Cellular and developmental control of O2 homeostasis by hypoxia-inducible factor $1 \alpha$. Genes \& Dev. 12: 149-162.

Jaakkola, P., Mole, D.R., Tian, Y.M., Wilson, M.I., Gielbert, J., Gaskell, S.J., Kriegsheim, A., Hebestreit, H.F., Mukherii, M., Schofield, C.J., et al. 2001. Targeting of HIF- $\alpha$ to the Von Hippel-Lindau ubiquitylation complex by O2-regulated prolyl hydroxylation. Science 292: 468-472.

Jiang, B.H., Agani, F., Passaniti, A., and Semenza, G.L. 1997 V-SRC induces expression of hypoxia-inducible factor 1 (HIF-1) and transcription of genes encoding vascular endothelial growth factor and enolase 1: Involvement of HIF-1 in tumor progression. Cancer Res. 57: 5328-5335.

Jiang, B.H., Jiang, G., Zheng, J.Z., Lu, Z., Hunter, T., and Vogt, P.K. 2001. Phosphatidylinositol 3-kinase signaling controls levels of hypoxia-inducible factor 1. Cell Growth Differ. 12: 363-369.

Karni, R., Dor, Y., Keshet, E., Meyuhas, O., and Levitzki, A. 2002. Activated pp60c-Src leads to elevated hypoxia-inducible factor (HIF)-1 $\alpha$ expression under normoxia. I. Biol. Chem. 277: 42919-42925.

Kasuno, K., Takabuchi, S., Fukuda, K., Kizaka-Kondoh, S., Yodoi, J., Adachi, T., Semenza, G.L., and Hirota, K. 2004. Nitric oxide induces hypoxia-inducible factor 1 activation that is dependent on MAPK and phosphatidylinositol 3-kinase signaling. J. Biol. Chem. 279: 2550-2558.

Kim, J.W., Tchernyshyov, I., Semenza, G.L., and Dang, C.V. 2006. HIF-1-mediated expression of pyruvate dehydrogenase kinase: A metabolic switch required for cellular adaptation to hypoxia. Cell Metab. 3: 177-185.

Koshiji, M., Kageyama, Y., Pete, E.A., Horikawa, I., Barrett, J.C., and Huang, L.E. 2004. HIF-1 $\alpha$ induces cell cycle arrest by functionally counteracting Myc. EMBO J. 23: 1949-1956.

Laughner, E., Taghavi, P., Chiles, K., Mahon, P.C., and Semenza, G.L. 2001. HER2 (neu) signaling increases the rate of hypoxia-inducible factor $1 \alpha(\mathrm{HIF}-1 \alpha)$ synthesis: Novel mechanism for HIF-1-mediated vascular endothelial growth factor expression. Mol. Cell. Biol. 21: 3995-4004.

Li, Y.M., Zhou, B.P., Deng, J., Pan, Y., Hay, N., and Hung, M.C. 2005. A hypoxia-independent hypoxia-inducible factor-1 activation pathway induced by phosphatidylinositol-3 kinase/ Akt in HER2 overexpressing cells. Cancer Res. 65: 32573263.

Lu, H., Dalgard, C.L., Mohyeldin, A., McFate, T., Tait, A.S., and Verma, A. 2005. Reversible inactivation of HIF-1 prolyl hydroxylases allows cell metabolism to control basal HIF-1. I. Biol. Chem. 280: 41928-41939.

Lum, J.J., Bauer, D.E., Kong, M., Harris, M.H., Li, C., Lindsten, T., and Thompson, C.B. 2005. Growth factor regulation of autophagy and cell survival in the absence of apoptosis. Cell 120: $237-248$.

Mansfield, K.D., Guzy, R.D., Pan, Y., Young, R.M., Cash, T.P., Schumacker, P.T., and Simon, M.C. 2005. Mitochondrial dysfunction resulting from loss of cytochrome c impairs cellular oxygen sensing and hypoxic HIF- $\alpha$ activation. Cell Metab. 1: 393-399.

Maxwell, P.H., Wiesener, M.S., Chang, G.W., Clifford, S.C., Vaux, E.C., Cockman, M.E., Wykoff, C.C., Pugh, C.W., Maher, E.R., and Ratcliffe, P.J. 1999. The tumour suppressor protein VHL targets hypoxia-inducible factors for oxygendependent proteolysis. Nature 399: 271-275.

Papandreou, I., Cairns, R.A., Fontana, L., Lim, A.L., and Denko, N.C. 2006. HIF-1 mediates adaptation to hypoxia by actively 
downregulating mitochondrial oxygen consumption. Cell Metab. 3: 187-197.

Pouyssegur, J., Dayan, F., and Mazure, N.M. 2006. Hypoxia signalling in cancer and approaches to enforce tumour regression. Nature 441: 437-443.

Rathmell, J.C., Vander Heiden, M.G., Harris, M.H., Frauwirth, K.A., and Thompson, C.B. 2000. In the absence of extrinsic signals, nutrient utilization by lymphocytes is insufficient to maintain either cell size or viability. Mol. Cell 6: 683-692.

Richard, D.E., Berra, E., Gothie, E., Roux, D., and Pouyssegur, J. 1999. p42/p44 mitogen-activated protein kinases phosphorylate hypoxia-inducible factor $1 \alpha(\mathrm{HIF}-1 \alpha)$ and enhance the transcriptional activity of HIF-1. J. Biol. Chem. 274: 3263132637.

Richard, D.E., Berra, E., and Pouyssegur, J. 2000. Nonhypoxic pathway mediates the induction of hypoxia-inducible factor $1 \alpha$ in vascular smooth muscle cells. J. Biol. Chem. 275: 26765-26771.

Ruderman, N.B., Saha, A.K., Vavvas, D., and Witters, L.A. 1999. Malonyl-CoA, fuel sensing, and insulin resistance. Am. I. Physiol. 276: E1-E18.

Ryan, H.E., Lo, J., and Johnson, R.S. 1998. HIF-1 $\alpha$ is required for solid tumor formation and embryonic vascularization. EMBO J. 17: 3005-3015.

Ryan, H.E., Poloni, M., McNulty, W., Elson, D., Gassmann, M., Arbeit, J.M., and Johnson, R.S. 2000. Hypoxia-inducible factor- $1 \alpha$ is a positive factor in solid tumor growth. Cancer Res. 60: 4010-4015.

Seagroves, T.N., Ryan, H.E., Lu, H., Wouters, B.G., Knapp, M., Thibault, P., Laderoute, K., and Johnson, R.S. 2001. Transcription factor HIF-1 is a necessary mediator of the pasteur effect in mammalian cells. Mol. Cell. Biol. 21: 3436-3444.

Selak, M.A., Armour, S.M., MacKenzie, E.D., Boulahbel, H., Watson, D.G., Mansfield, K.D., Pan, Y., Simon, M.C., Thompson, C.B., and Gottlieb, E. 2005. Succinate links TCA cycle dysfunction to oncogenesis by inhibiting HIF- $\alpha$ prolyl hydroxylase. Cancer Cell 7: 77-85.

Semenza, G.L. 2003. Targeting HIF-1 for cancer therapy. Nat. Rev. Cancer 3: 721-732.

Semenza, G.L., Jiang, B.H., Leung, S.W., Passantino, R., Concordet, J.P., Maire, P., and Giallongo, A. 1996. Hypoxia response elements in the aldolase A, enolase 1, and lactate dehydrogenase A gene promoters contain essential binding sites for hypoxia-inducible factor 1. J. Biol. Chem. 271: 32529-32537.

Vander Heiden, M.G., Plas, D.R., Rathmell, J.C., Fox, C.J., Harris, M.H., and Thompson, C.B. 2001. Growth factors can influence cell growth and survival through effects on glucose metabolism. Mol. Cell. Biol. 21: 5899-5912.

Wang, F.S., Wang, C.J., Chen, Y.J., Chang, P.R., Huang, Y.T., Sun, Y.C., Huang, H.C., Yang, Y.J., and Yang, K.D. 2004. Ras induction of superoxide activates ERK-dependent angiogenic transcription factor HIF- $1 \alpha$ and VEGF-A expression in shock wave-stimulated osteoblasts. I. Biol. Chem. 279: 1033110337.

Wang, M., Kirk, J.S., Venkataraman, S., Domann, F.E., Zhang, H.J., Schafer, F.Q., Flanagan, S.W., Weydert, C.J., Spitz, D.R., Buettner, G.R., et al. 2005. Manganese superoxide dismutase suppresses hypoxic induction of hypoxia-inducible factor- $1 \alpha$ and vascular endothelial growth factor. Oncogene 24: 81548166.

Wang, V., Davis, D.A., Haque, M., Huang, L.E., and Yarchoan, R. 2005. Differential gene up-regulation by hypoxia-inducible factor- $1 \alpha$ and hypoxia-inducible factor- $2 \alpha$ in HEK293T cells. Cancer Res. 65: 3299-3306.

Welford, S.M., Bedogni, B., Gradin, K., Poellinger, L., Broome Powell, M., and Giaccia, A.J. 2006. HIF1 $\{\alpha\}$ delays premature senescence through the activation of MIF. Genes \& Dev. 20: 3366-3371.

Yu, F., White, S.B., Zhao, Q., and Lee, F.S. 2001. HIF-1 $\alpha$ binding to VHL is regulated by stimulus-sensitive proline hydroxylation. Proc. Natl. Acad. Sci. 98: 9630-9635.

Zhong, H., De Marzo, A.M., Laughner, E., Lim, M., Hilton, D.A., Zagzag, D., Buechler, P., Isaacs, W.B., Semenza, G.L., and Simons, J.W. 1999. Overexpression of hypoxia-inducible factor $1 \alpha$ in common human cancers and their metastases. Cancer Res. 59: 5830-5835.

Zhong, H., Chiles, K., Feldser, D., Laughner, E., Hanrahan, C., Georgescu, M.M., Simons, J.W., and Semenza, G.L. 2000. Modulation of hypoxia-inducible factor $1 \alpha$ expression by the epidermal growth factor/phosphatidylinositol 3-kinase/ PTEN/AKT/FRAP pathway in human prostate cancer cells: Implications for tumor angiogenesis and therapeutics. Cancer Res. 60: 1541-1545. 


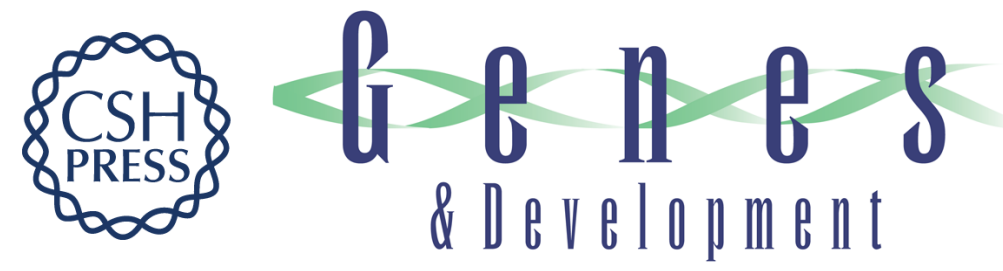

\section{The transcription factor HIF-1 $\alpha$ plays a critical role in the growth factor-dependent regulation of both aerobic and anaerobic glycolysis}

Julian J. Lum, Thi Bui, Michaela Gruber, et al.

Genes Dev. 2007, 21: originally published online April 16, 2007

Access the most recent version at doi:10.1101/gad.1529107

Supplemental
Material $\quad$ http://genesdev.cshlp.org/content/suppl/2007/04/16/gad.1529107.DC1

References This article cites 53 articles, 33 of which can be accessed free at:

http://genesdev.cshlp.org/content/21/9/1037.full.html\#ref-list-1

License

Email Alerting Receive free email alerts when new articles cite this article - sign up in the box at the top

Service right corner of the article or click here.

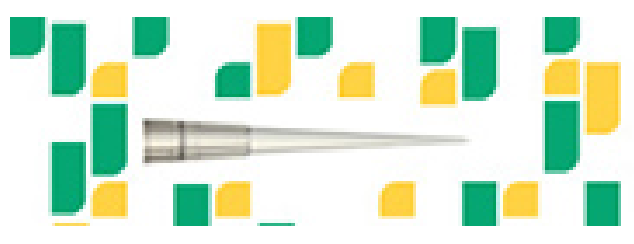

Focused on your science. 